\title{
Editorial to the INTERCOH 2017 topical collection
}

\section{Francisco Pedocchi ${ }^{1} \cdot$ Carl Friedrichs $^{2}$}

Published online: 24 August 2020

(C) Springer-Verlag GmbH Germany, part of Springer Nature 2020

Keywords INTERCOH $\cdot$ Cohesive sediments $\cdot$ Uruguay
INTERCOH 2017 was the 14th meeting of the International Conference on Cohesive Sediment Transport Processes. The INTERCOH biannual meetings gather the international community of scientists and engineers who have chosen to embrace the challenge of studying processes and finding solutions related to fine sediment issues in fluvial, estuarine, and marine environments. In these environments, cohesive sediment dynamics are often closely related to associated hydrodynamics, chemistry, and biology.

INTERCOH 2017 was held at the Instituto de Mecánica de los Fluidos e Ingeniería Ambiental (IMFIA), Facultad de Ingeniería, Universidad de la República, Montevideo Uruguay. This was the second time that the INTERCOH Meeting came to South America; the previous time was in 2009 in the cities of Rio de Janeiro and Paraty, Brazil (Vinzon et al. 2011). The need for engineering solutions in the Rio de la Plata and Montevideo Bay led to the early study of cohesive sediments in Uruguay. The Montevideo Port is literally built on mud, and dredging and construction in the area required the study of cohesive sediments in the area as early as 1871 (Fernández Saldaña and García de Zúñiga 2010). The "recent" study of cohesive sediments in the Universidad de la República started with the experiences of Oscar Maggiolo in the late 1960s and early 1970s (Gradowczyk et al. 1968; Maggiolo and Guarga 1972).

Responsible Editor: Jörg-Olaf Wolff

Francisco Pedocchi

kiko@ fing.edu.uy

Carl Friedrichs

Carl.Friedrichs@vims.edu

1 Instituto de Mecánica de los Fluidos e Ingeniería Ambiental, Universidad de la República, Julio Herrera y Reissig 565 CP 11300 , Montevideo, Uruguay

2 Virginia Institute of Marine Science, William \& Mary, Gloucester Point, VA, USA
Research on cohesive sediments largely stopped, as did most scientific studies in the country, in conjunction with the 11 years of political dictatorship, during which most of the research team that worked with Maggiolo was expelled from the University. With the return of democracy, cohesive sediment research at the Universidad de la República also returned in the newly reestablished IMFIA, and the work on cohesive sediments has continued for the following 30 years (Guarga et al. 1988; Piedra-Cueva 1993, 1995; Pedocchi and PiedraCueva 2005; Mosquera et al. 2014; Fossati et al. 2014; Groposo et al. 2015; Santoro et al. 2019).

More information on the past and future meetings and the activities of the cohesive sediment research community can be found at http://www.intercoh.org/. The book of abstracts of this edition can be found at https://www.fing.edu.uy/imfia/ intercoh. From the 97 abstracts that were presented during INTERCOH 2017, nine full-length publications are included in this Topical Collection of Ocean Dynamics.

The papers in this Topical Collection summarize the current research of groups across the globe, covering the topics of:

- Mud rheology and fluid mud: Assessing rheological properties of fluid mud samples through tuning fork data (Fonseca et al. 2019); Detection of fluid mud layers using tuning fork, dual frequency echo-sounder, and chirp subbottom measurements (Castro Carneiro et al. 2020).

- Suspended matter and flocculation: Investigating suspended particulate matter in coastal waters using the fractal theory (Chapalain et al. 2019); Temporal and spatial changes in grain size on a macrotidal channel-flat complex: results from Kingsport, Nova Scotia, Bay of Fundy (Law et al. 2019).

- Bed shear, erosion, and bed exchange: Modeling dynamics of the estuarine turbidity maximum and local net deposition (Hesse et al. 2019).

- Siltation, dredging, and plumes: Mud dynamics in the Port of Zeebrugge (Vanlede et al. 2019); field investigation of 
siltation at a tidal harbor: North Port of Incheon, Korea (Lee et al. 2019);

- Coastal and estuarine hydrodynamics: The relative impact of future storminess versus offshore dredging on suspended sediment concentration in a shallow coastal embayment: Rødsand lagoon, western Baltic Sea (Forsberg et al. 2019).

- Coastal and estuarine morphodynamics: Influence of morphological changes on suspended sediment dynamics in a macrotidal estuary: diachronic analysis in the Seine Estuary-France-from 1960 to 2010 (Grasso and Le Hir 2019).

Acknowledgments This 2017 edition of INTECOH was possible thanks to the work and help of several people. First, thanks to the Steering Committee, including Ashish Mehta and Han Winterwerp, for trusting us with the organization of the meeting. Also, thanks to Susana Vinzón, Erik Toorman, and Larry Sanford for their advice and tips for the organization of the meeting. In addition, thanks to the Local Committee (Mónica Fossati, Fernanda Maciel, Rodrigo Mosquera, Ismael PiedraCueva, and Pablo Santoro); Dominique von Thümen, who was in charge of the secretarial assistance; Gonzalo Rodriguez, who was in charge of the webpage and the informatics; the School of Engineering Accountant Office, which managed the funds; the School of Engineering Dean, María Simon; and the School Board for their support and allowing the use of the school facilities for the meeting. For their support and help during the event, thanks to Christian Chreties, Sebastián Solari, and Rodrigo Alonso, and to the Students at IMFIA: Michael Jackson, Daniela Martinez, Guillermo Echavarría, Manuel Teixeira, and María Ballesteros.

Finally, thanks for the support of the Sponsors: Delegación Uruguaya a la Comisión Técnico-Mixta de Salto Grande, Intendencia de Montevideo, Hidrovía S.A., Delegación Uruguaya a la Comisión Administradora del Río de la Plata, ANCAP, Saceem S.A. Your generosity was truly appreciated.

\section{References}

Castro Carneiro J, Gallo MN, Vinzón SB (2020) Detection of fluid mud layers using tuning fork, dual frequency echo-sounder, and chirp sub-bottom measurements. Ocean Dyn 70:573-590. https://doi. org/10.1007/s10236-020-01346-8

Chapalain M, Verney R, Fettweis M, Jacquet M, Le Berre D, Le Hir P (2019) Investigating suspended particulate matter in coastal waters using the fractal theory. Ocean Dyn 69:59-81. https://doi.org/10. 1007/s10236-018-1229-6

Fernández Saldaña JM, García de Zúñiga E (2010) Historia del Puerto de Montevideo - 2nd Edition. Montevideo. p 391. ISBN: 978-9974-00640-9 https://www.fing.edu.uy/node/4436

Fonseca DL, Marroig PC, Carneiro JC, Gallo MN, Vinzón SB (2019) Assessing rheological properties of fluid mud samples through tuning fork data. Ocean Dyn 69:51-57. https://doi.org/10.1007/ s10236-018-1226-9

Forsberg PL, Lumborg U, Andersen TJ, Kroon A, Brandbyge V (2019) The relative impact of future storminess versus offshore dredging on suspended sediment concentration in a shallow coastal embayment: Rødsand lagoon, western Baltic Sea. Ocean Dyn 69:475-487. https://doi.org/10.1007/s10236-019-01254-6

Fossati M, Cayocca F, Piedra-Cueva I (2014) Fine sediment dynamics in the Río de la Plata. Adv Geosci 39:75-80. https://doi.org/10.5194/ adgeo-39-75-2014

Gradowczyk MH, Maggiolo OJ, Folguera HC (1968) Localized scour in erodible-bed channels. J Hydraul Res 6(4):289-326. https://doi.org/ $10.1080 / 00221686809500242$

Grasso F, Le Hir P (2019) Influence of morphological changes on suspended sediment dynamics in a macrotidal estuary: diachronic analysis in the Seine Estuary (France) from 1960 to 2010. Ocean Dyn 69:83-100. https://doi.org/10.1007/s10236-018-1233-x

Groposo V, Mosquera R, Pedocchi F, Vinzón S, Gallo M (2015) Mud density prospection using a tuning fork. J Waterw Port Coast Ocean Eng ASCE 141(5):0401-4047. https://doi.org/10.1061/(ASCE) WW.1943-5460.0000289

Guarga R, Borghi J, Vinzón S, Piedra-Cueva I, Kaplan E (1988) Control y seguimiento de los estudios hidráulicos del Puerto de Montevideo efectuado por INTECSA. Technical Report. Facultad de Ingeniería, Universidad de la República, Montevideo, Uruguay. (in Spanish)

Hesse RF, Zorndt A, Fröhle P (2019) Modelling dynamics of the estuarine turbidity maximum and local net deposition. Ocean Dyn 69: 489-507. https://doi.org/10.1007/s10236-019-01250-w

Law BA, Hill PS, Milligan TG, Zions V (2019) Temporal and spatial changes in grain size on a macro-tidal channel-flat complex: results from Kingsport, Nova Scotia, Bay of Fundy. Ocean Dyn 69:239252. https://doi.org/10.1007/s10236-018-1237-6

Lee G, Shin H-J, Kim YT, Dellapenna TM, Kuk JK, Williams J, Kim SY, Figueroa SM (2019) Field investigation of siltation at a tidal harbor: North Port of Incheon, Korea. Ocean Dyn 69:1101-1120. https://doi.org/10.1007/s10236-019-01292-0

Maggiolo OJ, Guarga R (1972) Central Térmica Batlle y Ordóñez, Estudio Hidráulico de la toma de agua de refrigeración para la 5ta. y 6ta. unidades. Technical Report. Facultad de Ingeniería y Agrimensura, Universidad de la República, Montevideo, Uruguay. (in Spanish)

Mosquera R, Groposo V, Pedocchi F (2014) Acoustic measurements of a liquefied cohesive sediment bed under waves. Adv Geosci 39:1-7. https://doi.org/10.5194/adgeo-39-1-2014

Pedocchi F, Piedra-Cueva I (2005) Camp and Stein's velocity gradient formalization. J Environ Eng 131(10):1369-1376. https://doi.org/ 10.1061/(ASCE)0733-9372(2005)131:10(1369)

Piedra-Cueva I (1993) On the response of a muddy bottom to surface water waves. J Hydraul Res 31(5):681-696. https://doi.org/10.1080/ 00221689309498779

Piedra-Cueva I (1995) Drift velocity of spatially decaying waves in a twolayer viscous system. J Fluid Mech 299:217-239. https://doi.org/10. 1017/S002211209500348X

Santoro P, Fossati M, Tassi P, Huybrechts N, Pham Van Bang D, PiedraCueva I (2019) Effect of self-weight consolidation on a hydrosedimentological model for the Río de la Plata estuary. Int $\mathrm{J}$ Sediment Res 34(5):444-454. https://doi.org/10.1016/j.ijsrc.2018. 12.004

Vanlede J, Dujardin A, Fettweis M, Van Hoestenberghe T, Martens C (2019) Mud dynamics in the Port of Zeebrugge. Ocean Dyn 69: 1085-1099. https://doi.org/10.1007/s10236-019-01273-3

Vinzon SB, Mehta AJ, Winterwerp JC (2011) Editorial. Ocean Dyn 61: 155. https://doi.org/10.1007/s10236-011-0389-4 